\title{
International representations of Balkan wars: a socio- anthropological approach in international relations perspective
}

\author{
Enika Abazi (D) \\ Paris Peace Research Institute \\ Albert Doja \\ University of Lille
}

\begin{abstract}
This article introduces the socio-anthropological concept of international representations to examine the relationship between a civilizational rhetoric, the West European and the international politics of otherization and containment of Southeast Europe, and an essentialist and timeless bias in international relations theory, including both radical and constructivist trends. We first explore the different narrative perspectives on the Balkan wars from the beginning to the end of the twentieth century. Their subsequent problematization is aimed at challenging the way they have constructed commonplace and time-worn representations, which international society shares with different consequences in international affairs. This is a limited conception since international representations as a socio-anthropological concept are always socially, culturally and politically constructed, contested and negotiated. They do not neutrally refer to a reality in the world; they create a reality of their own. Moreover, this limited conception ignores the fact that how, by whom and in whose interest international representations are constructed is itself a form of power in international relations. Therefore, the way international representations are constructed can be problematized as an example of political and ideological projects that operate in the West as well as in the Southeast European countries that are the object of Western foreign policy.
\end{abstract}

\section{Introduction}

The main aim of this article is to problematize the dominant narratives of Balkan wars in terms of performative practices. We assume that these narratives are performed and practiced in ways that engender certain types of public representations in the West European imagination of not only the Balkan wars, but also

Earlier versions of this article were presented at a series of international conferences: The Balkan Wars 1912-1913: a conference to mark the 100th anniversary, organized by the Faculty of History, University of Oxford (UK), 17-18 October 2012; From Balkan Wars to Balkan peace project: the EU integration, organized by the Center for Strategic Research, Turkish Ministry of Foreign Affairs, in Tirana (Albania), 16 May 2012; The Balkan Wars 1912-1913: an international academic conference, organized by the Institut für Ost- und Südosteuropaforschung, Regensburg (Germany), in Tirana (Albania) 10-11 June 2013. We have benefitted greatly from the comments, encouragements, discussions and presentations of many participants, as well as from numerous friends and colleagues who have read parts of this paper at various stages and have helped to improve our argument: Nicholas Onuf, Sabrina Ramet, Mark Almond, Robert Evans, Tom Buchanan, James Pettifer, Maria Todorova, Bernd Fischer, Conrad Clewing, Leen d'Haenens, Thomas Lindemann, Chris Wright. We are also very grateful to the anonymous reviewers for their insightful comments and recommendations. 
Southeast Europe and its peoples. We analyse the performance of these narratives to attempt to understand how the international representations of Southeast Europe have been constructed throughout the twentieth century. ${ }^{1}$ In many ways, from the 1912-1913 Balkan wars to the Yugoslav conflicts in the 1990s, these representations have remained fixed in Western thought as a "present history", and they resonate with an historical and civilizational rhetoric that is linked to an othering process or a politics of "otherization". In particular, we highlight the inflated references to the atrocities of the Balkan wars, which continue to dominate the narratives on current events in the region. Such exaggerations revive old stereotypes and indiscriminate essentialized generalizations related to "non-European" qualifications, such as ancient hatred, violence and un-civilization. Incidentally, a similar essentialist and timeless bias can be found in the debates taking place in the field of international relations theory.

After a brief theoretical background, we first explore various narrative legacies of the Balkan wars in order to better understand the importance of discourse exerted by various ideological and political interests on the construction of the Balkan international representations of Southeast Europe. The key types of narrative and their legacy comprise sensationalist narratives, essentialist analyses, securitist concerns and pacifist appeals. Taken together as a whole, they are a common feature of contemporary policy and analysis in the dominant discursive practices of international politics and scholarship on Southeast Europe. Second, we consider some contingent problematizations with respect to the Balkan international representations of Southeast Europe, including the validity of claims in analytic approaches where historical knowledge is obtained from the interplays of temporality and historicity, the instrumental functions of ideas and performative practices at play in the otherization processes of Southeast Europe, and the "mytho-logical" rationalizations in West European and international politics and scholarship. Lastly, we explore some problematic outcomes of Southeast Europe being posited by Western observers and scholars as a security threat and a site of intervention. We also identify some of the reasons behind the international policy of containment of Southeast Europe and the theoretical confusion in international approaches to Western modernization, Europeanization and international society.

\section{Theoretical background}

Methodologically, we adopt a socio-anthropological approach that considers international representations in general and those of the Balkan wars in particular as forming a cultural system. In this sense, from the theoretical perspective of international relations advocated by Hedley Bull, the whole of ideas and beliefs on Southeast Europe can be considered to have been elaborated collectively by what is termed an 'international society of states' (Bull 1977) as imagined by the West. Following Durkheim, we consider that the international society elaborates, like any society, specific systems of 'collective representations' as an autonomous reality (Durkheim 1986, 46 [Eng. 63]). These representations would substantiate the intellectual attitudes of the Western international community independently from

\footnotetext{
${ }^{1}$ While arguing for considering Southeast Europe normally as an integral part of European history and politics, we also use "Southeast Europe" as a term much more appropriate than "the Balkans". It implicitly acknowledges the fact that Southeast Europe is a part of Europe, and correspondingly that the problems which have arisen are European and that solutions to these problems must be European.
} 
the individual mental images and dispositions of any given actor in the system. A similar social theoretical view also appears in influential writings on systemic constructivism. Alexander Wendt, for instance, maintains that in international politics 'collective representations have a life and logic of their own that cannot be reduced to actors' perceptions or behavior' (Wendt 1999, 264, see also 150-165).

From a socio-anthropological perspective, considering the specific cultural system of collective representations elaborated by international society also requires distinguishing the very relationship between culture and society. Throughout the history of anthropology, scholars have adapted the notions of culture to suit the dominant concerns of the day, thus making the anthropological account of culture 'something of a success story' (Kuper 1999, 226). From the Victorian anthropologist Edward Tylor (1871) to Clifford Geertz $(1973,1983)$ and beyond, in a powerful, complex and ongoing conceptualization, "culture" refers to an ordered system of acquired, cognitive and symbolic meanings and other resources of existence in terms of which social interaction takes place, whereas "society" refers to the social organization of human life, the ongoing process and pattern of interactive behaviour, the form that social action takes in the actually existing network of social relations (Geertz 1973, 144-145). In this sense, the ordered cultural system of particular beliefs, expressive symbols, values and representations that people use to define their world, express their feelings, interpret their experiences, make their judgments and guide their actions is specific to a given social entity. Seen from this perspective, the cultural system of beliefs, values and representations becomes a marker of difference between groups and a symbolic resource to confer identity on the group, whether this group is a society or a polity.

We might be right then to assume an international cultural system, which like any cultural system could be considered to consist of similar identity-conferring resources that are specific to Western international society as a social entity in its own right. These resources form a complex system of organized knowledge and belief based on cultural learning of symbols and codes, which allows international actors to structure their experiences and perceptions, formulate acts and choose between alternatives of internationally distributed and shared meanings. This does not necessarily prove that the identity of international actors, like any collective identity, ${ }^{2}$ can be organized, negotiated or manipulated independently of the cultural corporate content that is associated with the identities. As Fredrik Barth demonstrated, this only allows us to grasp the social effects of cultural corporate difference between the actors (Barth 1969). As Edmund Leach succinctly put it: 'Culture provides the form, the dress of the social situation' (Leach 1954, 16, emphasis given). That is to say, when seeking to understand the international cultural system, in line with a tradition that goes back to the founding fathers of French and British anthropology (Lévi-Strauss 1950; Radcliffe-Brown 1952), we should focus on the social and power relationships that are established through the allocation of roles and status between international actors, and not on their cultural characteristics or corporate resources.

Thus, what is important in the analysis of international representations is not any cultural content or corporate resources of particular actors, but rather the social organization of their differences, which make the various categories of cultural content and corporate resources organizationally relevant. In the process of

\footnotetext{
${ }^{2}$ For an illustrative substantiation of this argument, see Doja (2000).
} 
identification and otherization, only the cultural content and corporate resource 'which the actors themselves regard as significant' is used and taken into account according to the actual social situation in which they are engaged (Barth 1969, 14). The dynamics between the imposition and the acceptance of collective and corporate identities is grounded in the structural and transactional principle that real entities, whether social groups or state polities, are only constituted in relation to one another. Whatever the identity, as shown in several historical instances of Albanian identity reconstruction (Doja 2000), it is only applicable in reference to an otherness and can only be realized by a dichotomous group organization on the boundary of one in contact, confrontation or contrast with the other.

Accordingly, in the context of the international cultural system, a cultural content or corporate resource such as the truth claims about the representational and operational models of international society towards ideas, behaviours, facts or events imputed to Southeast Europe is not a causal concept. According to the logic of problematization, they appear in the form of problems with important interpretative and evaluative functions that need to be addressed. In the introduction to the Use of pleasure, Foucault defined a history of truth as 'a matter of analyzing, not behaviors or ideas, nor societies and their "ideologies", but the problematizations through which being offers itself to be, necessarily, thought—and the practices on the basis of which these problematizations are formed' (Foucault 1984, 11, emphasis given). Thus, Foucault provided a critical reflection on how complex practices contingently intersect to form the conditions of possibility for contemporary problems, which could allow us to better understand those more nuanced and meaningful interventions in international politics.

Properly understood as the articulation and intensification of problematizations (Koopman 2013), Foucault's genealogical method of cultural critique is a dual-dimensional method that designates both the objects and the acts of inquiry. As an object of inquiry, the problematization of empirical evidence and performative practices indicates the ways in which the emergence of new narratives has re-actualized previous problematic narratives of the Balkan wars as well as the ways in which they remain a problem to be addressed. As an act of inquiry, the problematization of empirical evidence and performative practices clarifies past problematizations that have enabled the development of present narrative practices, and intensifies our concern with those problematizations that continue to inform current ways of constituting the otherness in the international representations of Southeast Europe.

By problematizing the international representations of the Balkan wars, we can gain an understanding of how the legacies of the past and specific accounts have been interpreted to become the fixed reference point for "Balkanization" in the modern world. The degree to which the representations are equated with the civilizational characteristics of the region may further reveal the relationship between moral indignation and the development of both international policy and international theory. In this discussion, based both on Lévi-Strauss's structural anthropological perspective that lay stress on the systemic aspect of representations (Lévi-Strauss 1962) and on Foucault's genealogical method of cultural critique that emphasizes the hidden power relations in the workings of symbolic systems (Foucault 1975, 1976), the interdependent cultural elements of the international representations of Southeast Europe are considered and revealed as a whole, taking into account the different narrative legacies, contingent problematizations and problematic outcomes. 


\section{Narrative legacies}

The scholarly literature on the Balkan Wars has, for a number of reasons, remained incomplete and episodic. In some cases, these wars were eclipsed from memory due to the greater impact of the First World War. In others, works such as local historiographies were appropriated by nationalist political forces and used to serve their interests, thus providing a nationalistic bias on facts and events. Further, there was often a selective and partial usage of archival sources, which was exacerbated by the fact that they were difficult to access in their entirety due to language barriers. In addition, in various historical publications of the Cold War period, the issue of the Balkan wars is either not addressed or mentioned merely in passing. We see this in discussions of demographic displacements (Stavrianos 1956), the political establishment of Southeast European national states (Jelavich and Jelavich 1977), or when it is described simply as 'unmitigated violence that occurred in the sharing out of the booty' between warring parties (Hösch 1972, 142). Scholars appear to have glossed over the Balkan wars as a result of focusing on the ideological division between East and West and the realpolitik of the Cold War. In the 1990s, concurrently with the troubles in Yugoslavia, the 1913 Carnegie inquiry suddenly re-emerged to become the single most often-cited source, mistaken 'naively as a historical source' (Trix 2014, 148), on wars in Southeast Europe. ${ }^{3}$

If it is possible to have a picture of events during the Balkan Wars, it is difficult to make generalizations about the nature of wars based on the early narratives of different fact-finding missions and individual reports (Berri 1913; Durham 1914; Carnegie Endowment 1914; Hanotaux 1914; Young 1915; Trotsky 1980). Nevertheless, instances of war violence have been generalized and recast in many accounts of troubles in Southeast Europe. These accounts have been appropriated to construct an almost coherent framework for the discovery of sensational events, as if the advances of modernity were stopped in their tracks. From a book published before the Balkan wars broke out, we already learn that

history has [shown] that the Near East has been both the scene of and the reason for war after war. For a variety of reasons, this [region remains a continual threat to world peace]. The Balkan peninsula and Asia Minor may [never be free from] insurrection or massacre. (Woods 1911, 5)

\footnotetext{
${ }^{3}$ In August 1913, the Carnegie Endowment for International Peace created an International Commission of Inquiry to collect evidence for 'the causes and conduct of the Balkan wars' (Carnegie Endowment 1914). In the 1990s, a reprint of the 1913 Inquiry with a gratuitous caption on 'The Other Balkan Wars' (Carnegie Endowment 1993) and with a substantial introduction to 'The Balkan Crises 1913 and 1993' (Kennan 1993) left no room for doubt that conflict inherited from a distant tribal past prevailed in the same Balkan world. Later, a sequel on 'Unfinished Peace' tried to show the endurance of the pattern (Carnegie Endowment 1996). In a simple Google books search, just a single passage'Houses and whole villages reduced to ashes, unarmed and innocent populations massacred ... such were the means used by the Serbo-Montenegrin soldiery, with a view to the entire transformation of the ethnic character of regions inhabited exclusively by Albanians' (Carnegie Endowment 1914, 151) - is reproduced, sometimes verbatim in extenso, though more often truncated, in no fewer than 70 books and many thousands of press and journal articles, policy reports and other documents dealing with the wars of the disintegration of Yugoslavia in the 1990s. See <https://www.google.com/ search?q=Carnegie+1914+homes+ashes\&btnG=Chercher+des+livres\&tbm=bks\&tbo=1\&hl=fr\&gws $\mathrm{rd}=\mathrm{ssl}$ \#newwindow $=1 \& \mathrm{hl}=\mathrm{fr} \& \mathrm{tbm}=\mathrm{bks} \& \mathrm{q}=$ houses + and + whole + villages + reduced + to + ashes $\% 2 \mathrm{C}+$ unarmed+and+innocent+populations+massacr ed+with+a+view+to+t he+entire+transf ormation+of+ the+ethnic+character $>$ (Last accessed 11 November 2015).
} 
As another example, a single phrase in an acclaimed travel book illustrates the Western stereotype that developed of the timeless image of the Southeast European propensity for war and extreme violence: 'Violence was, indeed, all I knew of the Balkans' (West 1943, 375).

As Yugoslavia crumbled in the 1990s, the violence of the 1912-1913 Balkan wars re-emerged as a compelling factor in arguments in many books and reports, inspiring a sort of selective 'memory boom' (Winter 2006) and parading uncritically the brutalities of past Balkan wars before a watching world. Many commentators repeatedly overemphasized parallels between the barbarisms of the 1912-1913 Balkan wars and the Yugoslav conflicts in the 1990s. Actually, the casual reader of the international press, as represented for instance by the journalism of the North American and West European diplomatic and political establishment (Kaplan 1993; Kennan 1993; Cohen 1993; Gutman 1993; Rieff 1995; Glenny 1996; Judah 1997, 2002; Nation 2003; Gallagher 2007; Hislope 2007), has been left in little doubt that wars in the former Yugoslavia were endemic and primordial. Most of the commentators constructed a view according to which violence in Southeast Europe maintains an indefinite continued predominance that 'permits us to see the end in every beginning' (White 1987, 24). If violence was 'the leitmotif of the Balkans wars', 100 years ago there was a thoroughly negative estimation of Southeast Europe (Todorova 1997, 121). One hundred years later, war has remained a sure indicator of a Balkan predisposition towards destructive violence, and the primary reading path to an abnormal history of an indisputably non-modern, uncivilized Balkans (Michail 2012, 226).

In some among many academic conferences organized to commemorate the centenary of the 1912-1913 Balkan wars, we frequently came across different "truths" regarding historical facts, events, behaviours and their lasting significance for the region. ${ }^{4}$ As firmly held opinions and interpretations, they provide evidence that the Balkan wars continue to divide many of the peoples, the scholars and the states of the region and beyond. As indicated elsewhere (Abazi 2015), these interpretations may have prevented the arising of conditions under which an alternative representation and a critical theoretical narrative about war in Southeast Europe could be constructed and developed. Arguably, such alternatives are often prevented by the very diverse influences that have existed for so long and continue to exist today, such as sensationalism, essentialism, securitism or pacifism, to which we briefly call attention here.

\footnotetext{
${ }^{4}$ The Oxford conference in October 2012 stressed, with few exceptions, the supposed neutrality of Britain and Western Europe before the outbreak of the Great War (Pettifer and Buchanan 2015); the Tirana conference in June 2013, which was sponsored by the Regensburg Institute, showed ethnic atrocities perpetrated by Serbian armies against non-belligerent Albanians, while the Tirana conference in May 2012, sponsored by the Turkish Foreign Ministry, saw the insinuation of a supposed Albanian allegiance to Ottomanism. Other cases in point are the massive proceedings of a commemorative conference held in the US with the sponsorship of Turkish agencies, in which voice was frequently given to current Turkish views of Neo-Ottomanism (Yavuz and Blumi 2013), or a special issue of the Turkish Foreign Ministry Journal of International Affairs that was aimed at "overcoming prejudices, building bridges and constructing a common future" between Turkey and the Balkans (special issue, Perceptions vol. 18, no. 2 [2013]).
} 


\section{Sensationalism}

In the 1990s, as in the 1910s, the vast majority of writings are not produced by academic scholars. Many journalists, travelers and correspondents suddenly became Balkan "experts", simply by flying over the war zones for a few days or weeks, drawing on old stories, to report the same story. The very nature of their trade in search of sensations means that such narrators do not focus on a subject until it becomes a hot topic. They come prepared to 'witness rather than to analyze' (Stokes et al 1996, 141).

With the publication of $A$ witness to genocide, the highbrow international press found evidence for the 'horrors of ethnic cleansing' and 'the virus of aggressive nationalism' in Balkan social life, and reported that 'long-suppressed forces have been unleashed once more in the present' (Gutman 1993, 175). Indeed, according to one commentator, this 'mad war' could only be grasped if one turned back the clock and keep on going toward the past, as if what had happened in the past causally determined or inescapably motivated people in the present to kill and 'die for what their great-grandparents once did'. ${ }^{5}$ Thus, in various sensational narratives, we were told how the 'fragile peace shatters as Balkan hatred overflows', in the perpetual struggle of 'rival ethnic groups' killing each other 'for imagined national spaces'. ${ }^{6}$ In this narrative of the unreal, the ghosts of ethnic feuding revive in the Balkans: 'The Serbs hate the Albanians, who are not very keen on the Macedonians, who in turn have a mighty grudge against the Bulgarians, who are not very fond of the Turks, who are not exactly enamoured of the Greeks' ${ }^{\prime}$

The work of this group of Balkan "specialists" and "parachute journalists" targets mainly a non-specialist, non-academic audience, and purports to explain and unravel the intricacies of Balkan history and politics for lay readers. Many published books in this genre on Southeast Europe have achieved commercial success (Kaplan 1993; Cohen 1993; Gutman 1993; Rieff 1995; Judah 1997, 2002). These accounts may vary notoriously in quality and utility, but they all convey a very distinct perception of a loosely defined but contentious, dangerous and violence-prone area, which has long been reified as the exception to the international norm. Regardless of the fact that their target was the area of conflicts in the 1990s, the characteristics of this extraordinary situation in former Yugoslavia were extended to apply to Southeast Europe as a whole, completely without justification. The high-flown rhetoric of sensationalist journalistic coverage, countless policy-driven surveys and seller's case studies hawked the whole of Southeast Europe to the political class and to the general public who imagined it as "Balkan" (Todorova 2005, 153). This association is often taken to represent a complicated and irresolvable political situation based on complex and variegated division, fratricidal hatred and longstanding ethnic and religious grievances.

\footnotetext{
${ }^{5}$ Lenard J. Cohen (1992) '....And a mad, mad war', Washington Post, 15 December, 23.

${ }^{6}$ P. Beaumont and N. Wood (2001) 'Fragile Peace Shatters as Balkan Hatred Overflows', The Observer, 11 March.

${ }^{7}$ I. Traynor (1990) 'Ghosts of Ethnic Feuding Revive in the Balkans', The Guardian, 26 February, 7.
} 


\section{Essentialism}

Most local scholarship and politics in Southeast European countries contributed, albeit inadvertently, to such an outré reading of events, because their frameworks for thought remain narrowly nationalistic. This is also the case with some earlier contributions on the 1912-1913 Balkan wars by local scholars (e.g. Murzaku 1987), and many current accounts of the dissolution of Yugoslavia in the 1990s that are denounced as having been influenced by Serbian nationalist propaganda (for details, see Cushman 2004).

Accounts of particular national cultures by local scholars have often essentialized collective memories, which have been purveyed in some of the many publications on the Balkan wars by international scholars, who have reflected the atmosphere of the time by using 'historically pregnant names' (Campbell 1998, 40) in the titles of their books. They have included such expressions as Balkan babel, inferno, ghosts, broken bonds, tragedy, chaos, horrors, slaughterhouse, or "Third" and "Other" Balkan Wars (Kaplan 1993; Kennan 1993; Cohen 1993; Mojzes 1994; Woodward 1995; Glenny 1996; Ramet 2002). Many such publications assumed the kind of nationalism that is always seen as the underlying cause of mutual hatred. In such works, a common point of departure in their analysis 'seems to rely on an undeviating causal chain: people in the Balkans are nationalists, [which] generates mutual hatred, which under particular circumstances might lead to bloodshed' (Hatzopoulos 2003, 31).

Like sensationalist non-academic sources, reputedly more serious accounts also seemed to hold the view that from a historical perspective, 'the Balkan proclivity for ethno-religiously based violence [as] an explosion of intercommunal hatred and savagery was not at all surprising' (Cohen 1993, 270). Many believed that 'there is no ideology in the Balkans [that] matches nationalism's profound effect upon individuals and groups', simply because 'this accursed land was always prone to tectonic collisions, and those who have reignited the ethnoreligious hatreds have hurled entire nations into the inferno' (Mojzes 1994, 86). Similarly, others have observed more specifically how the 'struggle between Serbs and non-Serbs lies at the heart of the instability for which Yugoslavia was famous' (Ramet 2002, 1).

Such mystification of collective memory and nationalism 'distracts the reader from examining relevant evidence' (Ramet 2005, 3) that may warrant different, more accurate and more positive conclusions. Nevertheless, this unsound and hazardous conceptual framework is often taken at face value to fuel public international representations without problematization. Unfortunately, the same essentialist approach, which intersects with both social and political analyses of wars, is often reproduced in international relations writings to claim a distinct character of war in Southeast Europe. Further, this essentialist approach informs international attitudes towards Southeast Europe that result in acts of security containment that often trigger diverse securitist representations, to which we now turn.

\section{Securitism}

In presenting a securitist representation in the international attitudes towards Southeast Europe, we should distinguish the actual fact of securitization from the qualification of this fact. Of course, states may actually intervene in response to real and imminent threats to ensure their security. In other cases, intervention may be justified on the basis of a securitization logic that often creates threats rather 
than responds to them (Wæver 1995; Buzan et al 1998; Balzacq 2010). The threats so created and constructed by a securitization practice may refer to such existential matters as identity, religion, human rights, health, environment, etc. However, the securitization process can be qualified further as a securitism. ${ }^{8}$

While securitization or the creation of a security psychosis by means of discursive practices becomes a real issue of security and a real process that occurs out there in the world of politics, the qualifying specification of securitism would not refer to something out there in the world but to the values that underlie the securitization process. There is an axiological tendency in securitism that is worked out in the realm of the cultural system of beliefs and values as a collective representation or corporate resource. This tendency adopts the actual process of securitization and transforms it into an instrumental value that is delineated by a vision of how things are wished to be or ought to be. This carries with it implications for attitudes, patterns of behaviour and specific actions at the level of states, nations, societal groups and larger entities such as the European Union or Western Europe. Securitism may also apply to the Western-imagined "international society of states". In this case, it is grounded in the international cultural system of beliefs, representations, opinions and attitudes that promote a distinctive ideological and political boundary work of civilizational divides.

It is evident from the foregoing that the international representations of Southeast Europe that have been constructed from narratives of the violence perpetrated in the Balkan wars are important in that they help us understand the nature of international political agency in constructing the region as a threat to the existing international system. When an account of ethno-religious hatred and violence in Southeast Europe is constructed in terms of cultural or civilizational differences, civilized Europe is seen to be under threat from the savage Balkans, thereby making the region a target for securitist instrumentalization. Some may even argue that the Balkans stand as an affront and challenge to civilized Europe, both by virtue of their claim to be part of Europe and by their apparent ability to dramatically alter the course of Western history. It is easy to see how acceptance of this view would foster international representations and beliefs that the Balkans are a "powder keg" in Europe.

A full assessment of the perceptions of the part played by Southeast Europe in the world wars of 1914-1918 and 1941-1945 lies beyond the scope of this analysis, simply because in international representations they are never seen as "Balkan wars". Yet, it is worthwhile pointing out that commentators have long been perplexed by the fact that 'these wretched and unhappy little countries in the Balkan Peninsula' could have been the cause of a major global conflict, simply because of the shots fired in 1914 'in a mud-caked primitive village' (Gunther 1936, 437),

\footnotetext{
${ }^{8}$ The term "securitism" is formed with a suffix originally derived from Ancient Greek, reaching English through Latin via French. The same applies to other "isms", such as sensationalism, essentialism or pacifism, as well as Orientalism or Balkanism. According to the Oxford English Dictionary and the Grand Robert Dictionary of French, the suffix is often used to define an opinion system, an axiological tendency or a positive attitude towards a specific practice, behaviour, action, state, condition or social norm that a certain class or group of persons aims to promote, as a result of a distinctive principle, doctrine or ideology, typically a political ideology. Even though qualifying determinations may only be informed by popular opinion regarding the specific ideology, the suffix often indicates a pattern of qualification for the action or process or result indicated by the root word, such as in religionism, capitalism, nationalism, feminism, racism, sexism, humanrightsism and many others.
} 
which 'signaled the outbreak of World War I' (Todorova 1997). Similarly, the blueprint of conflict in Southeast Europe re-emerged in securitist narratives of the post-Cold War era, branding the region as a new force for trouble, specifically in terms of 'hyper-nationalism' (Mearsheimer 1990, 7-12; Mearsheimer and Pape 1993), "neo-tribalism" (Franck 1995; Tierney 2002), or rather vaguely as a 'Balkan Orient' with 'bloody borders' (Huntington 1996, 269). These factors are all identified as being likely to release suppressed ethnic-religious rivalries and ancient hatred, which could lead to the "Balkanization" of Europe, regardless of the existing order in international politics.

Focusing on the Yugoslav wars explicitly, many scholars have argued that the dynamics of disintegration in the region at the sub-state level cannot be accommodated within the Clausewitz definition of war as a rational instrument of state policy, and that they cannot be properly understood by focusing on traditional ideas about the causes, nature and impact of war in world politics (Van Creveld 1991; Holsti 1996; Huntington 1996; Kaplan 1997). One of these traditional ideas is that nationalism is the driving force of wars of nation-state building. However, while the question of aggressive nationalism is quite often associated with the Balkan wars and the Yugoslav conflicts in Southeast Europe (Glenny 1999; Pavkovic 2000; Yavuz and Blumi 2013), its relevance has been elevated by some to extreme proportions. Further, the nature of war itself is re-interpreted. In contrast to the descriptions of former inter-state wars in West Europe, wars in Southeast Europe are labelled "new" and "post-modern" wars of a "third kind" (Holsti 1992; Gray 1997; Kaldor 1999; Duffield 2001; Jung 2003).

In these arguments, it is not clear what constitutes "an unnatural conflict" specific to Southeast Europe. After all, the idea seems to have its genesis simply in the international politics and international representations, that came to constitute the West European idea of 'the Balkans as entrapment' (Hansen 2000, 355). This is what makes it necessary for Western Europe to adopt a politics of securitization and containment of Southeast Europe. As long as this attitude is comforting to those in Western Europe, it will continue to support the Balkan image in international representation and justify an international politics of further containment and otherization.

\section{Pacifism}

The 1913 Carnegie Inquiry into "the Causes and Conduct of the Balkan Wars", released in both French and English, offers a detailed and well-documented description of what happened in the 1912-1913 Balkan Wars. However, the title notwithstanding, the aim of the Carnegie Report was not to show the causes and conduct of the Balkan wars, but 'to inform public opinion' in the ambition to prevent war at all. In perfect compliance with classical idealistic thought and the pacifist agenda of the time, the authors set an ambitious task, explicitly claimed in the Preface to the Report:

if the minds of men can be turned even for a short time away from passion, from race antagonism and from national aggrandizement to a contemplation of the individual and national losses due to war, and to the shocking horrors which modern warfare entails, a step, and by no means a short one, will have been taken toward the substitution of justice for force in the settlement of international differences. (Carnegie Endowment 1914, Preface) 
Certainly, the international public outrage caused by the Balkan wars was a good opportunity to mobilize support for the pacifist agenda worldwide. The aim of this movement was to create a new framework for international relations based on the international law that would serve for the legal prevention of war between States. To this end, a number of conventions and declarations were drafted in the period preceding and following the 1913 Carnegie Inquiry that attempted to construct and codify the legal basis for States to engage in war (jus ad bellum), to impose limits on conduct in wartime (jus in bello), and to create institutions to manage and arbitrate disputes among States, through the establishment of institutions such as the Court of Arbitration established in 1899 in The Hague (Schindler and Toman 2004, 22-34).

The political and ideological developments of pacifism, which brought into being and sought to provide justification for the moral discourse of the West against misconduct in war, spurred the acknowledgment and inflated assessments of violence perpetrated in the Balkan wars as non-civilized and non-European atrocities and genocide. Thus, the way was paved for the otherization of Southeast Europe once again during the wars in Yugoslavia. The fact that the effect of this deplorable exhibition on the moral relations between the Western and the Near-Eastern peoples has been lamentable and will be lasting' (Young 1915, 378-379) also meant to Southeast Europe that she had to aspire to and attain Western "standards of civilization" (Gong 1984) to enjoy equal status in the European society of states.

\section{Contingent problematizations}

The publication of Imagining the Balkans (Todorova 1997) established "Balkanism" as an important concept that should be considered in debates on the problematization of the historical relationship between West and Southeast Europe as well as that of West European discourses through which Southeast European societies are Balkanized. Since then, a series of perceptive and critical interdisciplinary works intended for a specialist readership have demonstrated the growth of a theoretically sophisticated and politically aware scholarship in the field of Southeast European studies (Banac 1992; Almond 1994; Campbell 1998; Goldsworthy 1998; Bjelić and Savić 2002; Hatzopoulos 2003; Gagnon 2004; Cushman 2004; Green 2005; Hansen 2006; Biondich 2011). Some of these works relate directly to the issues of the 1912-1913 Balkan wars (Hansen 2000; Hall 2000; Farrar 2003; Kolev and Koulouri 2005; Kévonian 2008; Akhund 2012; Michail 2012; Simić 2013; Todorova 2013; Trix 2014; Abazi 2015). Triggered in the aftermath of the Yugoslav conflicts in the 1990s, most of the works have aimed to expose the hidden internal assumptions and contradictions of previous publications and subvert their influence on our understanding of the region and its image (Stokes et al 1996; Fleming 2000; Ramet 2005; Djokić and Ker-Lindsay 2011; Njaradi 2012; Ingrao and Emmert 2013).

In their wake, a new perspective can be presented on the narrative legacies of Balkan wars. The question is not merely reading the Balkan wars either as a "scoop" sold by the sensationalism of media industry and pseudo-academism, as a "mystification" stirred by the essentialism of collective memory, as a product of "aggressive" ethno-religious nationalism in the "great" history of threats 
securitized by the realism of state politics, or as a product of "genocide" in the "naïve" history of illegitimate war on which the idealism of pacifist activism has been imposed. The aim is rather to subject them to a genealogical critique of problematization, which requires a positioning about the validity of claims.

\section{Validity claims}

In a standard approach, the historical evidence that is used to validate the claims of international representations is normally subjected to critique on the grounds of factual accuracy and normative objectivity. After all, this is justified as long as validity claims are normally open to redemption or refutation through argumentation (Jones 1999, 111). Actually, a number of efforts in the growing field of critical Southeast European studies have convincingly demonstrated that the stereotypes and prejudices drawn on to construct the Balkan image of Southeast Europe in international representations unabatedly fly in the face of ample empirical evidence.

The pacifist agenda informed a Western geopolitical agenda, which aimed to provide Europe with an opportunity to recover its leading role in the world (Grossi 1994). In particular, D'Estournelles de Constant, the 1909 Peace Nobel Prize laureate and Head of the 1913 Carnegie Inquiry Commission, explicitly aimed to upgrade France's position as a "normative" power player on the world stage of international relations. Such a move was necessary, he believed, to face the political and economic dangers coming from the new emerging powers, especially against North American and East Asian threats, in his own words, 'le péril américain et le péril jaune' (Barcélo 1995, 17).

After all, 'the actions of states are determined not by moral principles and legal commitments but by considerations of interest and power' (Morgenthau 1970, 382). Such an interest-orientated attitude is clearly illustrated in the historical context of the decisions made by the European Powers in the Berlin Congress of 1878 that disrupted 'the normal development of the highly national conception of an alliance between the Balkan peoples' (Carnegie Endowment 1914, 40). These decisions frustrated national aspirations and paved the way for future wars in Southeast Europe: 'the direct and logical outcome of the Berlin settlement was the Serbian-Bulgarian war of 1885, the Bosnian crisis of 1908, the two Balkan wars of 1912-1913, and the murder of Archduke Francis Ferdinand in 1914' (Stavrianos 1956, 393, 412).

To fully understand the Balkan wars, they must be placed in the context of a broader global history of the twentieth century. In this context, it becomes evident that they are far from being an unusual event-that is to say, an instance of tribal warfare that lies beyond the pale in the eyes of civilized people. Rather, as Maria Todorova convincingly demonstrated, this is just another example of the homogenization of nations through population exchanges, the flight of refugees, border adjustments and genocidal massacres that are a dominant characteristic of the modern world (Todorova 2005). Also, in placing the Southeast in a broader European context, it might be useful to remember that European powers have committed colonial genocides in Africa, exterminated indigenous peoples in the Americas and perpetrated the Terror in Revolutionary France; implemented the Drang nach Osten policy of ethnic cleansing in East Europe and population exchanges in Southeast Europe; and, most importantly, were responsible for two 
World Wars, the second of which included the Holocaust in Europe and the use of nuclear weapons in Japan that killed millions in Hiroshima and Nagasaki, and caused untold damage to urban areas, the environment and future generations as a result of nuclear fallout.

Against this background, by problematizing the narrative accounts of Balkan wars, we may get some indication of exactly the sorts of issues that can be discussed throughout European contexts and temporalities. Nevertheless, the idea endures that a particularly abhorrent type of war is inevitable in Southeast Europe because ethno-religious hatred and hyper-nationalism are culturally embedded characteristics. Thus, it is the idea that there is something essentially different and culture specific about war that becomes questionable.

For instance, international representations of the Balkan wars might have changed and the meanings of violence shifted consistently (Michail 2012). Nationalism might have also been largely limited by the oscillations between the aggressive behaviour of military and political elites and the apathy, even hostility, of the peasantry majority toward war (Roudometof 2000; Farrar 2003; Hatzopoulos 2003). Moreover, information communicated by the various forms of media about events and politics might have been non-stereotypic, ambivalent and in some cases even positive (Dorn-Sezgin 2013). In yet other cases, it seems that the humanity of Southeast European peoples at war might have not been given the attention that it deserved (Kolev and Koulouri 2005; O'Loughlin 2010; Dimitrova 2013). Such studies have conclusively challenged the reified validity claims of ruthless violence, war atrocities, aggressive nationalism and dirty politics of the Balkan wars, or the "inhumanity" of Southeast European peoples, from the beginning to the end of the twentieth century (Campbell 1998).

In such approaches, however, important additional insights may be lost, simply because validity claims do not constitute representations by themselves. If a representational quality is always socially constructed, what seems to matter in this process is that beliefs and representations once constructed can hardly be challenged by questioning the factual accuracy and normative objectivity of the claims forwarded. From an expanded anthropological perspective following the Interpretation of cultures (Geertz 1973), we consider that international beliefs and representations in general and those of the Balkan wars in particular are constructed intersubjectively as a cultural system of hegemonic meanings internationally shared. They are defined, interpreted and negotiated in the course of international interactions, on a specific subject, based on a specific set of discursive acts, informed by specific knowledge and codes, which a specific set of international actors learn and put into practice. As such, international beliefs and representations allow the interpretation of situated experience and the generation of international political behavior, but they cannot be measured against some real or true facts derived from historical narratives and empirical evidence. Instead, as it were, the validity claims of the international hegemonic representations of Southeast Europe must relate to specific interactive and discursive social structures that facilitate the conditions for the claims to attain a representational status.

The discursive practice related to truth claims about facts, events and behaviours manifests itself in a way that both informs and is influenced by a particular imagination or narrative while leaving silent others, showing how some interpretations are empowered while others are undermined (Campbell 1998). In the Southeast European context as elsewhere, the role of ideas and discourses in the 
construction and reconstruction of war must first be clarified. If we aim to go beyond explanations based on rationalist interests, path-dependent history and cultural framing preferences, we must consider competing political interests. From this perspective, one inevitably needs to integrate a conceptual problematization of the constitutive factors of the dominant war narratives and related discursive and political practices. This requires an examination of the performative and instrumental functions of ideas and practices at play and their mytho-logical rationalizations, to which we now turn.

\section{Performative practices}

Dominant discourses in international representations are not simply signs that refer to or represent some reality, but a system of categories that makes a reality possible. To paraphrase Foucault in the Archaeology of knowledge, these discourses are not about objects of truth; they are practices that systematically constitute, in our case, the Balkan image of Southeast Europe as 'the object of which they speak' (Foucault 1969, 49). Arguably, from a symbolic-anthropological perspective that lay stress on the autonomous reality of the systems of representations (Geertz 1973), the international representations of the Balkan wars show the extent to which analytical categories of violence, ethnic-religious hatred and modernity, or civilized West and uncivilized Balkans, are often mistaken for empirical evidence of reality, which is detached from political practices and vested interests.

In particular, 'the discursive character of historical facts' assumes a performative and prescriptive function (Callinicos 1995, 76). In terms of realistic legacy, as long as collective representations of the Western-imagined international society of states 'have observable effects or are manipulable by human agents, we can in principle speak meaningfully about the "reality" of unobservable social structures' (Wendt 1987, 352). In the case of the international representations of Southeast Europe, their effects can be observed through the manipulation of reiterative and selective citational practices. The recurrent highlighting of particular memorialized images and analogies based on preconceived beliefs and perceptions of the Balkan wars and a bygone ethnicized violence (Kaplan 1993; Kennan 1993; Carnegie Endowment 1914, 1993, 1996) have led to a discursive reconstruction of Southeast Europe. This has brought into being a reality of "the Balkans" in international representations as a set of intercivilizational groups that tend to engage in the expansion and escalation of conflict (Huntington 1996, 272).

Most scholarly or semi-scholarly works on Southeast Europe have been written during times of crisis and this can be seen in the lasting representations that they have helped to construct. Often, these authors are interested in their subject matter simply because contemporary conflict makes the topic timely (Fleming 2000, 1226). While this might be a pragmatic approach, the opinionated apprehension of facts from previous crises to refer to current conflicts, as in the bloody disintegration of Yugoslavia or during the conflict in Kosovo, leads many journalists and scholars to hold what in other contexts are termed 'world views that may have both generated the catastrophe and narrated it afterwards' (Young 1988, 5).

A typical case in point is the introduction to the reprint of the 1913 Carnegie Inquiry, where the 1912-1913 Balkan wars are used to endow the Yugoslav conflicts in the 1990s with an inflated meaning. However blatant and fanciful it might 
seem, pre-given concepts are constructed upon which the criteria of judgment are based. Thus, the 'aggressive nationalism that manifests itself on the field of battle and drew on deeper traits of character inherited presumably from a distant tribal past ... had the effect of thrusting into the southeastern reaches of the European continent a salient of non-European civilization which has continued to the present day to preserve many of its non-European characteristics', while they inform 'the peoples of this age how much today's problem has deep roots' (Kennan 1993, 12-13).

An investigation of the discrete epistemic and discursive regularities marked by Southeast European discontinuities and ruptures provides insight into the contingency at work in historical practices. This can help us to see how international representations might be able to transform the present because they gain contingency by rendering the historical connection between the past and the present unintelligible. The use of empirical evidence from old wars to demonstrate the conditions of the present is not only misleading, but makes the early wars an intrinsic feature of the Balkan international representation of the latter-day Southeast Europe. The imposition of selected past practices upon recent events endows them both with the same everlasting meaning.

In the end, the circular pattern of representations reveals a form of self-fulfilled prophecy. If Southeast Europe is a very special place with very distinct people, one should not be surprised at the dramatic and rather cruel things that sometimes happen there. Believing in the uniqueness of one's background prepares people for unusual events, trains them not to be surprised by them and encourages them to cope with them. Most importantly perhaps, it inspires misperceptions about the exceptionality of war and the people who seemingly contradict the normative standards of war devised by the civilized world. This demonizes Southeast Europe and supports those who seek to securitize it and contain it from the rest of Europe. This creates a most difficult environment in which to broker lasting agreements and creates a justification for 'major and costly interventions of the international community' (Hajdarpašić 2009) in even wider conflicts.

\section{Mytho-logical rationalizations}

In the Western-imagined international society of states, violence is an inevitable product of politics and, incidentally, economics. By contrast, in Southeast Europe, it is often supposed to be the outcome of "ancient ethnic-religious hatred". Yet, when dealing with Balkan wars, two interrelated issues should also be considered. First and foremost, in international representations, the construction of violence in the Balkan wars is formulated in the context of a typology of differences according to a binary discourse on civilizations. It resonates with the almost "homeostatic qualities" of Southeast Europe as Europe's resident alien, an internal "other", constructed in contraposition to the rest of civilized Europe, in a disconnected geographical space and with its own historical time. As a typical example, the 1913 Carnegie Inquiry depicted Southeast European peoples as 'not far from us, [they] were then, and are still, unlike Europe, more widely separated from Europe than Europe from America; no one knew anything of them, no one said anything about them' (Carnegie Endowment 1914, 3). Much the same as anthropology once constructed its object with the "other" placed out of European time and out of 
European history (Wolf 1982; Fabian 1983), in this process, 'writing of Balkan violence as primeval or unmodern has become a way for the West to keep the desired distance from it' (Mazower 2002, 154).

Second and more problematic is the prejudice evident in the understanding of the history in Southeast Europe as well as the uses and abuses of history more generally (MacMillan 2001, 2009, 89). Perhaps this is best encapsulated in a phrase originally used in a restricted Cretan or Greek context but incorrectly attributed to Winston Churchill and generalized to "the Balkans" as a whole. ${ }^{9}$ As a typical Churchill aphorism, the belief that "the Balkans produce more history than they can consume" has been recycled and generalized by a good number of writers and politicians on Southeast Europe (Brown 2003). One example among others is that of the then-EU Commissioner for Enlargement who, in an address at the University of Sarajevo in 2005, advised the audience to leave blind nationalism behind and choose a European future, saying, 'I am sure you agree with me that it is high time that the Western Balkans can take a break and move from the production to the consumption of history!"'10

The arrogance of this aphorism allows us to bring together the two aspects, the otherization of Southeast Europe and the misperception of Southeast European history, and problematize them by using Lévi-Strauss's mytho-logical thermal analysis of history (Doja 2005, 2006, 2008a, 2008b). His claim that myths are machines for the suppression of time and disorder at the level of history and social relations (Lévi-Strauss 1964, 24 [Eng. 16]) and the distinction of 'historical temperatures' in his model of 'cold' and 'hot' societies (Lévi-Strauss 1961, 37-48 [Eng. 32-42]) can be applied to see international representations as a cooling machine in the hot power game of international politics.

From this point of view, one inevitably tends to integrate international politics in a system of logical transformations and adopt the theoretical perspective of international agency in historical change. Without a doubt, the "hot" processes of warfare in European history are systematically followed by the "cooling" mechanisms of peace in international order, such as in Westphalia (1648), Vienna (1814-1815), Berlin (1878), Versailles (1919), Yalta (1945) or Dayton (1995), to name but a few. Apparently interested in practical plans, more often than not, European powers are consumed by political myths. The cooling device of international peace treaties is not dissimilar to that of the myths of the so-called primitive peoples. In Lévi-Strauss's sense, both European powers and primitive peoples might have managed to work out a reasonable way to insert the irrationality of war and calamity into some kind of rationality. By means of their own ceaseless logical transformations, as outlined elsewhere (Doja 2008a), in one case or another, myths generate the appearance of stability, an illusion of timelessness that cannot be affected by changes in the world. Therefore, the peace treaties, as processes of ongoing logical transformations of the system of international relations, also serve as a cooling mystification machine for the obliteration of hot history, 'even and particularly that which might be thought to defy the system' (Lévi-Strauss 1962, 323 [Eng. 243]).

\footnotetext{
${ }^{9}$ The overstated catchphrase credited to Winston Churchill is taken from a Scottish short-story writer and humourist: 'the people of Crete unfortunately make more history than they can consume locally'. Saki, pseudonym of Hector Hugh Munro (1870-1916), "The Jesting of Arlington Stringham", Chronicles of Clovis, 1911 (Quoted in the Oxford Dictionary of Quotations).

10 "The Balkans, Europe and Reconciliation", Speech by EU Commissioner Olli Rehn to students at Sarajevo University on 11 July 2005, http:/ / www.westernbalkans.info/htmls/save_pdf2.php?id=779.
} 
Similarly, the way the Churchill aphorism is taken from creative writing into political discourse underpins its mytho-logical transformational qualities. By arguing specifically that Southeast European peoples tend to produce more history than they can consume, one inevitably tends to cool down the history of horrible tragedies, wars and other plagues in one's own society by blaming them on "other" histories. In other words, this aphorism is being used to give the illusion ("it goes without saying, on a purely symbolic level") that violence, war atrocity, ancient ethnic-religious hatred and the like are somebody else's business. The argument that Southeast European peoples might have complex histories that should be taken at distance from the ongoing progress of West European civilization makes it plain that West European powers, as Lévi-Strauss showed for the so-called cold societies in similar contexts, "deploy all their efforts and they spend boundless ingenuity", in the hope, which is certainly vain, to maintain the international society of West European civilization "intact against the dangers coming from inside and from outside" (Lévi-Strauss 1993, 10).

International interest groups try to give meaning and significance to facts by using formal and informal institutions and any possible medium of communication. An analysis of the historical conditions of possibility of the present ways of doing, being and thinking among such interest groups is required to reveal and understand the ways in which the particular events of the Balkan Wars are represented and often affect what they themselves believe and claim to be the truth. International representations and beliefs may comply with the needs of political and ideological projects furthered at a given time, and which might have been inspired and fuelled by the fervours of sensational essentialism or realist securitism or idealist pacifism during the Balkan wars. However, they can also be the effect of unrelenting militarism, fascism, communism, internationalism, multiculturalism, civilizationism, religionism, human rights-ism and any other kind of fundamentalism that is coming next. Therefore, problematization may allow us to move from a historical inquiry that lacks critical purchase to a form of cultural critique that could act as a turning point between professional scholarship and the problematic outcomes of international politics and theory, to which we now turn.

\section{Problematic outcomes}

Violence as a signifier of international representations of Southeast Europe is an everlasting normative and ideational Western assumption based on 'the governing codes of subjectivity in international relations' (Campbell 1998, 170). That is why the same prescriptive international representational codes underlying the normative and ideational structures upon which the violence of the 1912-1913 Balkan wars was qualified in different narratives re-emerged aggressively to guide the public understanding of the forceful dissolution of Yugoslavia in the 1990s. The ideas and beliefs that emerged from these discursive codes of subjectivity seem to have been successful in constructing a distorted essential identity of Southeast Europe that has remained unchanged in spite of substantial changes in practice.

The contingent problematization of the meaning of the Balkan wars in international representations can shed light on the historical conditions of the possibility 
of practices that have induced uncompromising, inflexible, constant and causal beliefs. These beliefs and representations seem to have left their mark on public opinions, academic accounts and international politics in relation to Southeast Europe. The essentialist way in which Southeast Europe is represented and the belief that Southeast European societies have a specific set of cultural characteristics constitutes a reference point in the Western-imagined international society of states. This is a reference point for understanding and misunderstanding the current situation. It seems to make past events constrain, legitimize, justify or excuse the political behaviour and attitudes of national and international actors in current times. The same representations lend weight to continuous misperceptions of international relations on a more global scale as well as to misleading trends in social and political theories of international relations.

\section{Securitization and containment}

The southeastern part of Europe was for a long time the border between the Islamic world of the Ottoman Empire and the Christian West of European empires, and the relative power of each of these competing forces may be seen in the political and religious structures of the region. However, early on, Southeast Europe became a 'neutral, non-political and non-ideological concept which abolished the standing historical-political dichotomy between the Danubian Monarchy and the Ottoman Balkans that had become irrelevant' (Bernath 1973, 142). Later, it even became, as shown in the case of Albania (Abazi 2004a), an integral part of the European and Mediterranean security environment.

However, the dominant discourse on the Balkan Wars prompted an international representation that clearly affected the West European and international approach to interventions in the 1990s. International politics was not based on Southeast European political developments and moral considerations in the aftermath of the Cold War, but on the consequences that the Yugoslav conflicts might have for West European security and international order. Intense journalistic coverage kept the conflicts in the limelight in North America and Western Europe. Policymakers often used the worst examples of that coverage, such as the "Balkan Ghosts" or the "Other Balkan Wars" (Kaplan 1993; Kennan 1993) to support or excuse their views, decisions and policies (Hajdarpašić 2009), particularly regarding securitizing and containing the Yugoslav conflicts in Bosnia (Hansen 2006) and Kosovo (Abazi 2004b). Such an attitude may also explain the otherwise unconceivable international motivation behind the notorious delay of humanitarian and military interventions in Bosnia as well as the later ambiguous policy of socioeconomic and political transformation towards Southeast Europe as a whole (Balfour 2008). Unfortunately, current West European policy attitudes seem still to be determined by a similar subjectivity, which has resulted in an endless process of the European integration of the so-called Western Balkans (Seroka 2008; Petersen 2011; Braniff 2011; Bechev 2011; Sotiropoulos and Veremis 2012; Dzihic and Hamilton 2012).

In contrast to the Balkans as a geographical notion of a mountain range on the Balkan Peninsula, the "Western Balkans" is a new political term coined at the 1998 European Council in Vienna. The new term, which is defined in EU discourses as the "former Yugoslavia, excluding Slovenia, including Albania", indicates the 
sub-regional target of West European and international policy in a selective way of "differentiated integration" (Dyson and Sepos 2010), specifically regarding the accession of the remaining Southeast European countries to EU membership. There is nothing that sets apart the so-called "Western Balkans" from other neighbouring countries. They all share, albeit in different proportions, a common historical and cultural legacy that is grounded in the Habsburg, the Ottoman or the Soviet imperial ruptures (Abazi 2008a, 232). The Western Balkans are actually defined by what they are not (Petrovic 2009, 30). They are not EU members, and there is not an "Eastern" counterpart but only the "Western Balkans" and the European Union. This awkward situation is even more complicated with Croatia becoming an EU member in 2013, thus detaching itself from the "Western Balkans" as a political entity, which will become even more meaningless when eventually all its remaining countries will join the EU.

As a geographical and a political term, "Western Balkans" fulfils two parallel functions that are not synonymous but homonymous: 'they do not cover the same area of meaning and their functioning is backed by different ideological mechanisms' (Petrovic 2009, 34). While the "Western Balkans" can be accepted and used as a geographic signifier, like "the Balkans" at an earlier time, 'it is already becoming saturated with a social and cultural meaning that has expanded its signified far beyond its immediate and concrete meaning' (Todorova 1997, 21). Interestingly, the long-standing, culturally laden connotations of the attributes of the "West" and the "East" in this context are actually reversed. That part of Southeast Europe that was depicted as the most disturbing, the most nationalistic and the most violent during the 1990s has been reinvented under an apparently sanitized label of "Western" Balkans. However, this re-branding also reinforces in a peculiar way the earlier Balkanized discourses by endorsing the perception that these former Yugoslav countries typify the perennial "Balkan" problem because they deviated from the normative course of post-socialist transition and for a while sank into the worst excesses of nationalism (Hajdarpašić 2009). Ultimately, the "Western Balkans" become an ideal replacement for the "Balkan Other" as a whole, which is essential for maintaining this otherization.

Southeast European countries that are candidates for EU membership are undoubtedly seen as 'part of Europe', and it is 'where they belong historically and in terms of civilization' (Petrovic 2009, 25). Indeed, their belonging is emphasized in constant ideological claims in both EU and Southeast European political discourses (Abazi 2008a, 230-237). However, the discourse that legitimizes the integration of individual Southeast European states in the European Union is performed through the selective reference to or deliberate omission of certain historical legacies, the choice of which is predicated on the degree of "Europeanism" assigned to West and East European societies (Petrovic 2009, 65). Within this ambiguous space in which Europeanism is a given for some countries, while others have to work for it (Hammond 2006, 8), an ideal arena appears for the shaping of a new European Balkanism that places Southeast European countries in the position of a colonized subject.

Discourse on the accession of the "Western Balkans" to EU membership reintroduces Southeast Europe as a European periphery in need of supervision by Western Europe, an idea that has been around since the 1910s: 'Once these fertile countries were linked to the rest of Europe and connected like the rest of Europe, they would of themselves become peaceful by means of commerce and trade and 
industry, enriching themselves in spite of their inextricable divisions' (Carnegie Endowment 1914,8). It seems that not much has changed in the current context as there appears to be a re-actualization of the long-established patterns of GermanAustrian colonial practices and the colonial discourse of West European domination. Moreover, the established traditions of scholarship, as shown elsewhere in more detail in relation to German-speaking Albanologie (Doja 2014a, 2014b) and native Albanian studies (Doja 1998, 2015), have enabled the political elites in both the EU and Southeast European countries to openly articulate and appropriate a new colonial discourse of Balkanism, which is legitimated through the EU accession process.

The West European policy of differentiated integration, and more generally the harmful international policy of securitization and containment of Southeast Europe, may have unintended consequences, as shown elsewhere more specifically in the case of Kosovo (Doja 2001; Abazi 2004b, 2008b), in terms of the continuous misperceptions of international relations on a more global scale. A combination of factors, such as the end of Cold War ideologies and the invigoration of new ideologies of integral nationalism, civilizational fundamentalism and international terrorism, increases the chances that regional leaders will be able to seize power and shift allegiance to their advantage very quickly. Thus, we are no longer dealing with an internal Eastern question or simply with a Western representational issue, but with global Realpolitik. Western Europe is increasingly under the pressure of competing global powers, but if it misrepresents Southeast Europe, this would be detrimental to Europe as a whole. If Southeast Europe is not recognized in full representational and political terms as an integral part of Europe, this may alienate the whole region, individual countries at the state level or certain members of the population at an individual level, and engage them in other potential conflicts (Lindemann 2010, 2014), or push them to look further to the East, perhaps not to the old Eastern Communism, but to the new Eastern power of Russian Pan-Slavism, or even to Neo-Ottomanism and fundamental Islamism. A new propaganda machine is working industriously to elaborate new international representations in that direction, and this machine already includes a certain activism and scholarship that aim at "Reinstating the Ottomans" anew in Southeast Europe as elsewhere in the Middle East (Blumi 2011).

\section{Theoretical confusion}

The essentialist elaboration of international representations of Southeast Europe also informs certain trends in the social and political theory of international relations. These include both the radical realist theses of the "clash of civilizations" (Huntington 1996) and the social constructivist theses of "collective identity formation" (Wendt 1994). Actually, both Samuel Huntington and Alexander Wendt remain attached to the prescriptive character of collectively held ideas about identity, in terms of collective memory, culture, religion, language and history at the level of a given society. In the case of Southeast European societies, the Balkan wars are described as 'fault line wars' between essentialized civilizations (Huntington 1996, 269-272) or as wars caused by 'primordial ethnic hatred' (Wendt 1999, 163). 
From the social constructivist standpoint (Wendt 1999), the social identities of states are thought to be constituted by the normative and ideational structures of international society that ascribe a status, role or personality to a state, while the corporate sources of state identity are thought to refer to internal human, material and ideological, or cultural factors that make a state what it is (Reus-Smit 2002, 494-495). Wendt believes that the identity of the state informs its interests and, in turn, its actions. However, in his distinction between social and corporate identities of the state, he is unable to conceptualize adequately the external (international) and internal (corporate) sources of identity ascription and self-ascription. Unexpectedly from the standpoint of the theoretical concept of culture, an essentialist position is surreptitiously introduced in understanding cultural corporate resources, while the external international domain and the domestic political realm are mistakenly confused.

The power and complexity of the expanded anthropological perspective following the Interpretation of cultures (Geertz 1973) lies in a basic understanding of culture as a complex set of interdependent abstractions built from social relationships and from the conceptions and meanings that members of a social or corporate group broadly share. This makes it possible to see how power relationships are defined and constructed, interpreted and negotiated in social interaction. As such, culture cannot have a concrete existence as a "thing" out there, even though it is located and transmitted within social groups. The social transmission of culture tends to unify people within a group by providing a common experience, which tends to generate a common and implicit understanding of future events. Thus, a group's members share a culture that is distinct from other cultures, simply because members of a given group are differently cultured from members of other social or corporate groups. In this sense, culture becomes a marker of difference between groups and an identity-conferring resource for the group. In turn, this is the simple reason why the concept started to be used in plural in the sense of humankind being divided into a number of separate and distinct cultures. In the plural sense, however, the concept has been used and misused in ways that often lead to the dangerous reification and racialization of culture itself, in the assumptions that cultures are associated with given groups of people, have clear boundaries and are somehow timeless and unchanging.

Without doubt, social groups, and hence states, are in the first instance collections of individual actors sharing a common self-ascription, but with no necessary relation to any particular cultural corporate content. There is much controversy in social theory, but the point that the cultural content and the meaning of collective identity are open to change and redefinition, after its initial inception, is not contested. Actually, since the classic approach initiated by Fredrik Barth's introduction to Ethnic groups and boundaries (Barth 1969), it became more profitable to focus in anthropology and social theory on the analysis of the foundation and maintenance of group boundaries, rather than on the cultural characteristics of any particular group. ${ }^{11}$

Oddly enough for Wendt, "collective memory" seems to be still a key "cognitive resource" that helps explain "the relative ease" with which Southeast European peoples respond aggressively to each other's actions, as well as 'the larger aggregate tendency for such seemingly irrational conflict to recur over time' (Wendt

\footnotetext{
${ }^{11}$ For an illustrative case, see Doja (2000).
} 
1999, 163). As a proximate expedient, this might be right if it were an essentialist argument at the level of the internal domestic realm, but it cannot work in terms of a systemic constructivist argument at the level of external international affairs. Collective representations of the permanence of primordial ethnic-religious hatred and nationalism, violence and war atrocities, civilization and un-civilization cannot be part of a Southeast European cultural system, but must be considered at another, external macro-level. Rather, from a social theoretical perspective of international relations, they form an ideological system at the level of the Western-imagined "international society" that includes states and organizations, policymakers and opinion makers, geopolitical strategists and specialists, travelers, journalists and scholars. It is the micro-level role relationships based on the frequent subjective images and perceptions of these actors in their social interaction with Southeast European societies that create the Balkan "generalized Other" (Mead 1934) to be embedded in the macro-level collective representations of international society. The "reality" of these social structures is perhaps unobservable, but the collective representations that form the cultural and ideological system of international society, which is manipulated at will by its human agents, have lasting observable effects.

The international representations of Southeast Europe are constantly manipulated through social interactions and discursive practices. As such, they are necessarily constructed as a specific cultural trait of the Western-imagined international society of states. Contrary to what we are taught to believe, it is not the historical past, the enumeration of Southeast European cultural traits or the cultural inventory of Southeast European collective memories that shape and essentialize the identity of the "backward" Balkans and characterize the "Balkan" nature of wars. Eventually, the constancy of international representations cannot be explained by referring to the historical and cultural diversity of actors in a purported civilized Western Europe and an uncivilized Southeastern Europe, but rather by recognizing the repeated occurrence of certain, rather than other, deliberate patterns of biased interaction between West and Southeast European actors across time.

From such a transactional perspective, the prescriptive character of international representations of Southeast Europe must be a function of the continuous maintenance of an imagined cultural boundary with Western Europe, defined by a long sociocultural interaction. A careful examination of the social organization of cultural boundaries between "backward" Southeast Europe and "civilized" West Europe clearly shows that they are not the implication or the outcome of either Southeast European or West European identities. It is rather the establishment, the maintenance and the perpetuation of a cultural boundary that creates and recreates these identities by constantly signifying them. These boundaries are actually derived from a deliberate process of negotiations to establish structures that are 'comparable to potential governance structures', which define the 'sets of acceptable contracting partners' (Somer 2001, 146), along 'a series of constraints on the kinds of roles [one] is allowed to play and the partners one may choose for different kinds of transactions' (Barth 1969, 17).

\section{Conclusion}

The pervasive character of idealist and realist discourses on the Balkan Wars may appear unusual and difficult to grasp, if one employs traditional categories that are developed in sensationalist, essentialist, pacifist and securitist accounts 
of both scholarship and politics. However, an analysis of the narrative legacies, when linked to a careful examination of their historical contextualization from an ideological perspective, can result in a more critical understanding of the politics of international representations of Southeast Europe. In attempting to analyse the history and the politics of the Balkan wars, the aim of this article was to frame the argument in such a way as to focus on the problematization of different accounts and move away from the close association of the Balkan wars with the essentialization of Southeast Europe. We have argued here that the discursive performative practice of many accounts has created a distorted representation of Southeast Europe in international society, which has been used as a justification for policies of securitization and containment of Southeast Europe and has led to confusion in international relations theory. Finally, the side effect of this situation seems to be a potential underestimation of the pressing problems at both regional and global levels, whereas Southeast Europe must be considered an integral part of European history and politics.

In methodological terms, we undertook a comparative analysis of ideas rather than a search for an extended positive proof. We adopted a critical approach to the politics of representations by focusing on the political processes and power relations that define wars and their representations in international relations. The problematization of representational narratives and practices related to the Balkan wars has revealed new insights on the politics of international representations. The aim of this article was not to write a history of Balkan wars, but rather to examine how their international representations have defined the West European imagination of Southeast Europe. While this approach might not have resulted in an exhaustive treatment and certainly a number of questions remain open, it is hoped that the discussion herein will provoke at the very least a non-stereotyped debate on the effects of essentializing concepts and representations, and will result in further, deeper enquiries in this direction. Ultimately, through this discussion we have aimed to show the extent to which writings about the Balkan wars can create and represent another, unsuspected reality, that of collective representations in the Western-imagined international society of states, a topic which this article showed that we must start to deal more seriously with, both in the arena of international politics and in the field of international relations theory.

\section{Notes on contributors}

Enika Abazi (PhD in international relations, Bilkent University, 2005) is the director of the Paris Peace Research Institute (France). A tenured associate professor of international relations and the director of the Institute for Balkan Studies at the European University, Tirana (Albania), she has held visiting positions at the Faculty of Social and Economic Sciences and the Doctoral College, University of Lille, and at the Institute of Political Studies, Sciences Po, Rennes (France). She also has significant experience in the management of education, serving on temporary assignment to the United Nations Development Programme (UNDP) as a founding Dean and Deputy Rector of Research at the European University, Tirana, and at the University of Durres (Albania). A former research fellow of the Copenhagen Peace Research Institute (COPRI) and principal investigator in many research projects at several European research institutions, including Centre lillois d'études et de recherches sociologiques et économiques (Clersé), Geneva 
Centre for the Democratic Control of Armed Forces (DCAF), Hellenic Foundation for European \& Foreign Policy (ELIAMEP), Turkish Asian Center for Strategic Studies (TASAM), Foundation for Political, Economic and Social Research (SETA) and the Albanian Institute for International Studies (AIIS), she has participated in several international symposia and conferences and she has so far published a couple of books, many book chapters and articles in peer-reviewed and indexed academic journals. Her research interests include critical approaches to war and ethnic conflicts, security and normative aspects of international interventions, institutional design and cultural dimensions of Southeast European regional security, European Union integration and enlargement toward Southeast Europe. Email: enika.abazi@unipax.eu

Albert Doja is a full professor of sociology and anthropology at the University of Lille, France, and an ordinary full member of the National Academy of Sciences, Albania, holding the first chair of anthropology. He was awarded a PhD with distinction in social anthropology (1993) from the Paris École des Hautes Études en Sciences Sociales (EHESS), and a professorial accreditation (Habilitation à Diriger des Recherches) in sociology and anthropology (2004) from Paris Descartes University, Sorbonne, qualifying for full university professorship within the French academic system. A former honorary fellow of the Department of Anthropology at University College London and on temporary assignment to the UNDP as the founding vice-chancellor of the new University of Durres, Albania, he has held several academic positions in France, Britain, Ireland and Albania, lectured on social anthropology and conducted extensive fieldwork research in many other countries. He is on the editorial board of international academic journals and he has so far published a couple of books and many original articles in international peer-reviewed and indexed journals (http:/ / www.researcherid. com/rid/C-1637-2008). His research interests include politics of knowledge, power and ideology; anthropology of symbolism and religion, intercultural communication, interethnic relations and international migrations; comparative politics of identity transformations and European integration; identity structures, discourses, practices and processes; technologies of the self, personhood, gender construction, kinship and reproduction activism; anthropological theory, structural analysis, post-structuralism and neo-structuralism. Email: albert. doja@univ-lille1.fr

\section{Disclosure statement}

No potential conflict of interest was reported by the authors.

\section{ORCID}

Enika Abazi (D) http:/ / orcid.org/0000-0003-2482-5691

Albert Doja (D) http:/ / orcid.org/0000-0001-5378-8362 


\section{References}

Abazi, Enika (2004a) 'Defence reform of the Albanian armed forces: democratization and transformation', Connections: The Quartery Journal, 3:3, 29-38

Abazi, Enika (2004b) 'The role of international community in conflict situation: which way forwards? The case of the Kosovo/a conflict', Balkanologie: Revue d'études pluridisciplinaires, 8:1, 9-31

Abazi, Enika (2008a) 'Albania in Europe: perspectives and challenges', Eurasian Files (Avrasya Dosyasi): International Relations and Strategic Studies, 14:1, 229-252

Abazi, Enika (2008b) 'A new power play in the Balkans: Kosovo's independence', Insight Turkey, 10:2, 67-80

Abazi, Enika (2015) 'Between facts and interpretations: three images of the Balkan wars 1912-1913' in James Pettifer and Tom Buchanan (eds) War in the Balkans: conflict and diplomacy before world war I (London: I.B.Tauris), 201-225

Akhund, Nadine (2012) 'The two carnegie reports: from the Balkan expedition of 1913 to the Albanian trip of 1921 - a comparative approach', Balkanologie: Revue d'études pluridisciplinaires, 14:1-2

Almond, Mark (1994) Europe's backyard war: the war in the Balkans (London: Mandarin)

Balfour, Rosa (ed) (2008) The Balkans in Europe: containment or transformation? Twelve ideas for action economic and social life (Brussel: EPC)

Balzacq, Thierry (2010) 'Constructivism and securitization studies' in Myriam Dunn Cavelty \& Victor Mauer (eds.) Routledge handbook of security studies (New York, NY: Routledge), 56-72

Banac, Ivo (1992) 'The fearful asymmetry of war: the causes and consequences of Yugoslavia's demise', Daedalus: Journal of the American Academy of Arts and Sciences, $121: 2,142-158$

Barcélo, Laurent (1995) Paul d'Estournelles de Constant, prix Nobel 1909. L'expression d'une idée européenne (Paris: L'Harmattan)

Barth, Fredrik (1969) 'Introduction' in Ethnic groups and boundaries: the social organization of culture difference (London: Allen-Unwin), 9-38

Bechev, Dimitar (2011) Constructing South East Europe: the politics of Balkan regional cooperation (London: Palgrave-Macmillan)

Bernath, Mathias (1973) 'Südosteuropäische Geschichte als gesonderte Disziplin'. Forschungen zur osteuropäischen Geschichte (Wiesbaden: Harrassowitz)

Berri, Gino (1913) L'Assedio di Scutari. Sei mesi dentro la citta accerchiata (Milano: Treves)

Biondich, Mark (2011) The Balkans: revolution, war, and political violence since 1878 (Oxford: Oxford University Press)

Bjelić, Dušan and Obrad Savić (eds) (2002) Balkan as metaphor: between globalization and fragmentation (Cambridge, Mass.: MIT Press)

Blumi, Isa (2011) Reinstating the Ottomans: alternative Balkan modernities, 1800-1912 (New York, NY: Palgrave-Macmillan)

Braniff, Maire (2011) Integrating the Balkans: conflict resolution and the impact of EU expansion (London: Tauris)

Brown, Keith (2003) The past in question: modern Macedonia and the uncertainties of nation (Princeton, N.J.: Princeton University Press)

Bull, Hedley (1977) The anarchical society: a study of order in world politics (New York, NY: Columbia University Press), 4th edition, 2012

Buzan, Barry, Ole Wæver and Jaap de Wilde (1998) Security: a new framework for analysis (London: Lynne Reinner)

Callinicos, Alex (1995) Theories and narratives: reflections on the philosophy of history (Cambridge: Polity Press)

Campbell, David (1998) National deconstruction: violence, identity, and justice in Bosnia (Minneapolis, MN: University of Minnesota Press)

Carnegie Endowment (ed) (1914) Report of the international commission to inquire into the causes and conduct of the Balkan wars (Washington)

Carnegie Endowment (ed) (1993) The other Balkan wars: a 1913 Carnegie endowment inquiry in retrospect, with a new introduction and reflections on the present conflict by George Kennan (Washington) 
Carnegie Endowment (ed) (1996) Unfinished peace: report of international commission on the Balkans (Washington)

Cohen, Lenard (1993) Broken bonds: the disintegration of Yugoslavia (Boulder: Westview)

Cushman, Thomas (2004) 'Anthropology and genocide in the Balkans: an analysis of conceptual practices of power', Anthropological Theory, 4:1, 5-28

Dimitrova, Snezhana (2013) 'The Balkan war evidences - another war heritage: a study of soldiers' notebooks, letters and drawings', Paper presented at the International Conference: the Balkan wars 1912-1913, 11-12 June 2013 (Tirana: Regensburg Institut für Ost- und Südosteuropaforschung and Tirana Institute for Southeast European Studies), $<<$ http:/ / balkanologie.revues.org/2365>>, accessed 11 January 2016

Djokić, Dejan and James Ker-Lindsay (eds) (2011) New perspectives on Yugoslavia: key issues and controversies (New York, NY: Routledge)

Doja, Albert (1998) 'Évolution et folklorisation des traditions culturelles', East European Quarterly, 32:1, 95-126

Doja, Albert (2000) 'The politics of religion in the reconstruction of identities: the Albanian situation', Critique of Anthropology, 20:4, 421-438

Doja, Albert (2001) 'Démocratie et stabilité dans le Sud-Est Européen: facteurs humains, culturels et sociaux', Les Temps Modernes, 56:615-616, 147-166

Doja, Albert (2005) 'The advent of heroic anthropology in the history of ideas', Journal of the History of Ideas, 66:4, 633-650

Doja, Albert (2006) 'The shoulders of our giants: Claude Lévi-Strauss and his legacy in current anthropology', Social Science Information, 45:1, 79-107

Doja, Albert (2008a) 'Claude Lévi-Strauss at his Centennial: toward a future anthropology', Theory, Culture E Society, 25:7-8, 321-340

Doja, Albert (2008b) 'From neolithic naturalness to tristes tropiques: the emergence of LéviStrauss's new humanism', Theory, Culture E Society, 25:1, 77-100

Doja, Albert (2014) 'The beautiful blue danube and the accursed black mountain wreath: German and Austrian kulturpolitik of knowledge on Southeast Europe and Albania', Soziale Welt: Zeitschrift für sozialwissenschaftliche Forschung und Praxis, 65:3, 317-343

Doja, Albert (2014b) 'From the German-speaking point of view: Unholy Empire, Balkanism, and the culture circle particularism of Albanian studies', Critique of Anthropology, 34:3, 290-326

Doja, Albert (2015) 'From the native point of view: an insider/outsider perspective on folkloric archaism and modern anthropology in Albania', History of the Human Sciences, 28:4, 44-75

Dorn-Sezgin, Pamela (2013) 'Between cross and crescent: British diplomacy and press opinion toward the Ottoman Empire in resolving the Balkan Wars, 1912-1913' in Hakan Yavuz and Isa Blumi (eds) War and nationalism: the Balkan Wars, 1912-1913, and their Sociopolitical Implications (Salt Lake City, UT: University of Utah Press), 423-473

Duffield, Mark (2001) Global governance and the new wars: the merging of development and security (London: Zed)

Durham, Edith M (1914) The struggle for scutary (London: Edward Arnold)

Durkheim, Emile (1986) De la division du travail social (Paris: Presses Universitaires de France), original edition, 1893; transl H D Halls (1984) The division of labor in society (New York, NY: Macmillan)

Dyson, Kenneth and Angelos Sepos (eds) (2010) Whose Europe? The politics of differentiated integration (Basingstoke: Palgrave-Macmillan)

Dzihic, Vedran and Daniel Hamilton (eds) (2012) Unfinished business: the Western Balkans and the international community (Washington: CTR)

Fabian, Johannes (1983) Time and the other: how anthropology makes its object (New York, NY: Columbia University Press)

Farrar, LL (2003) 'Aggression versus Apathy: the limits of nationalism during the Balkan wars 1912-1913', East European Quarterly, 37:3, 257-280

Fleming, Katherine (2000) 'Orientalism, the Balkans, and Balkan historiography', American Historical Review, 105:4, 1218-1233

Foucault, Michel (1969) L'Archéologie du savoir (Paris: Gallimard); transl Alan Sharidan (1972) The archaeology of knowledge (London: Tavistock) 
Foucault, Michel (1975) Surveiller et punir: naissance de la prison (Paris: Gallimard); transl Alan Sheridan (1977) Discipline and punish: the birth of the prison (London: Allen Lane)

Foucault, Michel (1976) La volonté de savoir, Histoire de la sexualité, 1 (Paris: Gallimard); transl Robert Hurley (1978) The history of sexuality: an introduction (New York, NY: Pantheon Books)

Foucault, Michel (1984) L'usage des plaisirs, Histoire de la sexualité, 2 (Paris: Gallimard); transl Robert Hurley (1985) The use of Pleasure (New York, NY: Pantheon Books)

Franck, Thomas (1995) Fairness in international law and institutions (Oxford: Oxford University Press)

Gagnon, VP (2004) The Myth of ethnic war: Serbia and Croatia in the 1990s (Ithaca: Cornell University Press)

Gallagher, Tom (2007) The Balkans in the new millennium: in the shadow of war and peace (New Jersey: Routledge)

Geertz, Clifford (1973) The interpretation of cultures (New York, NY: Basic Books)

Geertz, Clifford (1983) Local knowledge: further essays in interpretive anthropology (New York, NY: Basic Books)

Glenny, Misha (1996) The Fall of Yugoslavia: the third Balkan war (London: Penguin)

Glenny, Misha (1999) The Balkans: Nationalism, War and Greats Powers 1804-1999 (London: Granta Books)

Goldsworthy, Vesna (1998) Inventing Ruritania: the imperialism of the imagination (New Haven, CT: Yale University Press)

Gong, Gerrit (1984) The standards of civilization in international society (Oxford: Clarendon Press)

Gray, Chris (1997) Post-modern war: the new politics of conflicts (London/New York: Routledge)

Green, Sarah (2005) Notes from the Balkans: locating marginality and ambiguity on the GreekAlbanian border (Princeton: Princeton University Press)

Grossi, Verdiana (1994) Le Pacifisme Européen, 1889-1914 (Bruxelles: Bruylant)

Gunther, John (1936) Inside Europe (New York/London: Harper)

Gutman, Roy (1993) A witness to Genocide: the first inside account of the horrors of ethnic cleansing in Bosnia (New York, NY: Macmillan)

Hajdarpašić, Edin (2009) 'Locations of knowledge: area studies, nationalism, and theory in Balkan studies since 1989', Kakanien Revisited, <<http://www.kakanien.ac.at/beitr/ balkans/EHajdarpasic1.pdf $>>$

Hall, Richard (2000) The Balkan wars 1912-1913: Prelude to the first world war (London: Routledge)

Hammond, Andrew (2006) 'Balkanism in political context: from the Ottoman Empire to the EU', Westminster Papers in Communication and Culture, 3:3, 6-26

Hanotaux, Gabriele (1914) La Guerre des Balkans et l'Europe (1912-1913) (Paris: Plon)

Hansen, Lene (2000) 'Past as preface: civilizational politics and the 'Third' Balkan war', Journal of Peace Research, 37:3, 345-362

Hansen, Lene (2006) Security as practice: discourse analysis and the Bosnian war (London: Routledge)

Hatzopoulos, Pavlos (2003) 'All that is, is nationalist: Western imaginings of the Balkans since the Yugoslav Wars', Journal of Southern Europe E the Balkans, 5:1, 25-38

Hislope, Robert (2007) 'From expressive to actionable hatred: ethnic division and Riot in Macedonia' in Craig J Jenkins and Esther E Gottlieb (eds) Identity conflicts: can violence be regulated? (New Brunswick, N.J.: Transaction Publishers), 149-166

Holsti, Kalevi (1992) 'International theory and war in the Third World' in Brian Job (ed) The Insecurity Dilemma: National security of the third world states (Boulder, Colo.: L. Rienner), $37-60$

Holsti, Kalevi (1996) The state, war and the state of war (Cambridge: Cambridge University Press)

Hösch, Edgar (1972) The Balkans: a short history from Greek times to the present day (London)

Huntington, Samuel (1996) The clash of civilizations and the remaking of world order (London: Simon \& Schuster)

Ingrao, Charles and Thomas Emmert (eds) (2013) Confronting the Yugoslav controversies: a scholars' initiative (West Lafayette, Ind.: Purdue University Press) 
Jelavich, Charles and Barbara Jelavich (1977) The establishment of the Balkan National States, 1804-1920, a history of East Central Europe (Seattle, WA: University of Washington Press)

Jones, Richard-Wyn (1999) Security, strategy, and critical theory (Boulder: Lynne Rienner)

Judah, Tim (1997) The Serbs: history, myth and the destruction of Yugoslavia (New Haven, CT: Yale University Press)

Judah, Tim (2002) Kosovo: war and revenge (New Haven, CT: Yale University Press)

Jung, Dietrich (2003) Shadow globalization, ethnic-conflict and new wars: a political economy of intra-state war (London: Routledge)

Kaldor, Mary (1999) New and old wars: organized violence in a global era (Cambridge, UK: Polity Press)

Kaplan, Robert (1993) Balkan ghosts: a journey through history (New York, NY: Picador)

Kaplan, Robert (1997) The end of the Earth: a journey at the dawn of the twentieth century (London: Papermac)

Kennan, George (1993) 'Introduction: the Balkan crises 1913 and 1993'. The Other Balkan Wars: A 1913 Carnegie Endowment Inquiry in Retrospect, with a new introduction and reflections on the present conflict (Washington: CEIP)

Kévonian, Dzovinar (2008) 'L'Enquête, le Délit, la Preuve: les «Atrocités» Balkaniques de 1912-1913 à l'Épreuve du Droit de la Guerre', Le Mouvement Social, 222:1, 13-40

Kolev, Valery and Christina Koulouri (2005) The Balkan wars, teaching modern Southeast European History, 3 (Thessaloniki: CDR)

Koopman, Colin (2013) Genealogy as critique: Foucault and the problems of modernity (Bloomington: Indiana University Press)

Kuper, Adam (1999) Culture: the anthropologists' account (Cambridge, Mass: Harvard University Press)

Leach, Edmund (1954) Political systems of highland Burma: a study of Kachin social structure (Cambridge, Mass.: Harvard University Press)

Lévi-Strauss, Claude (1950) 'Introduction à l'œuvre de Marcel Mauss', Marcel Mauss. Sociologie et Anthropologie (Paris: PUF), IX-LII; English translation in book-length edition (London: Routledge, 1987)

Lévi-Strauss, Claude (1961) Entretiens avec Claude Lévi-Strauss, by Georges Charbonnier (Paris: Plon); transl (London: Cape, 1969)

Lévi-Strauss, Claude (1962) La pensée sauvage (Paris: Plon); transl The Savage Mind (London: Weidenfeld-Nicolson, 1966)

Lévi-Strauss, Claude (1964) Le Cru et le Cuit , Mythologiques, 1 (Paris: Plon); transl John and Doreen Weightman (1969) The raw and the cooked: introduction to a science of mythology (New York, NY: Harper-Row)

Lévi-Strauss, Claude (1993) 'Un autre regard', L'Homme: Revue Française d'Anthropologie, 33:126-128, 7-10

Lindemann, Thomas (2010) Causes of war: the struggle for recognition (Colchester: ECPR Press)

Lindemann, Thomas (2014) 'Interest, passion, (non)recognition, and wars: a conceptual essay', Global Discourse: An Interdisciplinary Journal of Current Affairs and Applied Contemporary Thought, 4:4, 483-496

MacMillan, Margaret (2001) Peacemakers: the Paris conference of 1919 and its attempt to end war (London: Murray)

MacMillan, Margaret (2009) Dangerous games: the uses and abuses of history (New York, NY: Modern Library)

Mazower, Mark (2002) The Balkans: a short story (New York, NY: Modern Library)

Mead, George-Herbert (1934) Mind, self and society, from the standpoint of a social behaviorist Charles W. Morris (eds) (Chicago: University of Chicago Press)

Mearsheimer, John (1990) 'Back to the future: instability in Europe after the cold war', International Security, 15:1, 5-56

Mearsheimer, John and Robert Pape (1993) 'The answer: a three-way partition plan for Bosnia and how the U.S. can enforce it', The New Republic, June, 22-28

Michail, Eugene (2012) 'Western attitudes to war in the Balkans and the shifting meanings of violence, 1912-91', Journal of Contemporary History, 47:2, 219-239

Mojzes, P (1994) Yugoslavian inferno: Ethnoreligious warfare in the Balkans (New York, NY: Continuum) 
Morgenthau, Hans (1970) Truth and power: essays of a decade, 1960-70 (New York, NY: Praeger) Murzaku, Thoma (1987) Politika e Serbisë kundrejt Shqipërisë gjatë Luftës Ballkanike 1912-1913 (Tirana: Akademia Shkencave)

Nation, Craig (2003) War in the Balkans, 1991-2002 (Washington: Strategic Studies Institute)

Njaradi, Dunja (2012) 'The Balkan studies: history, post-colonialism and critical regionalism', Debatte: Journal of Contemporary Central and Eastern Europe, 20:2-3, 185-201

O'Loughlin, John (2010) 'Inter-ethnic friendships in post-war Bosnia-Herzegovina: sociodemographic and place influences', Ethnicities, 10:1, 26-53

Pavkovic, Stevan (2000) The fragmentation of Yugoslavia: Nationalism and War in the Balkans (Basingstoke: Macmillan)

Petersen, Roger (2011) Western intervention in the Balkans: the strategic use of emotion in conflict (Cambridge: Cambridge University Press)

Petrovic, Tanja (2009) A long Way home: representations of the western Balkans in political and media discourses (Ljubljana: Mirovni Institut)

Pettifer, James and Tom Buchanan (eds) (2015) War in the Balkans: conflict and diplomacy before world war I (London: I.B.Tauris)

Radcliffe-Brown, Alfred (1952) Structure and function in primitive society (London: Cohen \& West)

Ramet, Sabrina (2002) Balkan babel: the disintegration of Yugoslavia from the death of Tito to the fall of Miloševic (Boulder: Westview), 4th edition, original edition, 1992

Ramet, Sabrina (2005) Thinking about Yugoslavia: scholarly debates about the Yugoslav breakup and the war in Bosnia and Kosovo (Cambridge: Cambridge University Press)

Reus-Smit, Christian (2002) 'Imagining society: constructivism and the English school', The British Journal of Politics and International Relations, 4:3, 487-509

Rieff, David (1995) Slaughterhouse: Bosnia and the failure of the West (New York, NY: Simon \& Schuster)

Roudometof, Victor (2000) 'The social origins of Balkan politics: nationalism, underdevelopment, and the national-state in Greece, Serbia, and Bulgaria, 1880-1920', Mediterranean Quarterly, 11:3, 151-167

Schindler, Dietrich and Jiri Toman (eds) (2004) The laws of armed conflicts: a collection of conventions, resolutions, and other documents (Boston, MA: Martinus Nihjoff)

Seroka, Jim (2008) 'Issues with regional reintegration of the Western Balkans', Journal of Southern Europe and the Balkans, 10:1, 15-29

Simić, Predrag (2013) 'Balkans and Balkanisation: Western perceptions of the Balkans in the Carnegie Commission's reports on the Balkan Wars from 1914 to 1996', Perceptions: Journal of International Affairs, 18:2, 113-134

Somer, Murat (2001) 'Cascades of ethnic polarization: lessons from Yugoslavia', Annals of the American Academy of Political and Social Science, 573:1, 127-151

Sotiropoulos, Dimitri and Thanos Veremis (eds) (2012) Is Southeastern Europe doomed to instability? A regional perspective (London: Routledge)

Stavrianos, Leften-Stavros (1956) The Balkans since 1453 (London: Hurst)

Stokes, Gale, John Lampe, Rusinow Dennison and Julie Mostov (1996) 'Instant history: understanding the wars of Yugoslav succession', Slavic Review, 55:1, 136-160

Tierney, Stephen (2002) 'The search for a New normativity: Thomas Franck, Post-modern Neo-tribalism and the Law of Self-determination', European Journal of International Law, 13:4, 941-960

Todorova, Maria (1997) Imagining the Balkans (New York, NY: Oxford University Press), Reprint edition, 2009

Todorova, Maria (2005) 'The trap of backwardness: modernity, temporality, and the study of Eastern European Nationalism', Slavic Review, 64:1, 140-164

Todorova, Maria (2013) 'War and memory: Trotsky's War correspondence from the Balkan Wars', Perceptions: Journal of International Affairs, 18:2, 5-27

Trix, Frances (2014) 'Peace-mongering in 1913: the Carnegie international commission of inquiry and its report on the Balkan Wars', First World War Studies, 5:2, 147-162

Trotsky, Leon (1980) The Balkan wars 1912-13: the war correspondence of Leon Trotsky [Balkany i Balkanskaia voina]; Transl Brian Pearce George Weissman and Duncan Williams (eds) (New York, NY: Monad), original edition, 1926

Tylor, Edward (1871) Primitive culture: researches into the development of mythology, philosophy, religion, art and custom (London: Murray) 
VanCreveld, Martin (1991) The transformation of war (New York, NY: Free Press)

Wæver, Ole (1995) 'Securitization and desecuritization' in Ronnie D Lipschutz (ed) On security (New York, NY: Columbia University Press), 46-86

Wendt, Alexander (1987) 'The agent-structure problem in international relations theory', International Organization, 41:3, 335-370

Wendt, Alexander (1994) 'Collective identity formation and the international state', American Political Science Review, 88:2, 384-396

Wendt, Alexander (1999) Social theory of international politics (Cambridge: Cambridge University Press)

West, Rebecca (1943) Black lamb and grey Falcon: a journey through Yugoslavia (London)

White, Hayden (1987) 'The value of narrativity in the representaion of reality' in Hayden White (ed) The content of the form: narrative discourse and historical representaion (Baltimore, MD: Johns Hopkins University Press), 1-25

Winter, Jay (2006) "The generation of memory: reflections on the "Memory Boom" in contemporary historical studies', Bulletin of the German Historical Institute, 27: 69-92

Wolf, Eric (1982) Europe and the people without history (Berkeley: University of California Press)

Woods, Henry-Charles (1911) The danger zone of Europe: changes and problems in the near East (London: Unwin)

Woodward, Susan (1995) Balkan Tragedy: Chaos and dissolution after the cold war (Washington: Brookings Institution)

Yavuz, Hakan and Isa Blumi (eds) (2013) War and Nationalism: the Balkan wars, 1912-1913, and their sociopolitical implications (Salt Lake City, UT: University of Utah Press)

Young, George (1915) Nationalism and war in the near East (Oxford: Clarendon)

Young, James (1988) Writing and rewriting the holocaust: narrative and the consequences of interpretation (Bloomington: Indiana University Press) 